\title{
Foot Care and Risk of Diabetic Foot in Patient with Type 2 Diabetes at H. Adam Malik Hospital Medan
}

\author{
Yesi Ariani ${ }^{1}$, Rosina Br Tarigan ${ }^{2}$, Aron Pase ${ }^{3}$ \\ ${ }^{1.2}$ Faculty of Nursing, University of Sumatera Utara, Indonesia \\ yesiariani@yahoo.com \\ kutabasamegmail.com \\ ${ }^{3}$ Faculty of Medicine, University of Sumatera Utara, Indonesia \\ aronpase@ymail.com
}

\begin{abstract}
Type 2 diabetes is a chronic disease which if not controlled can cause complications. One of the complications of type 2 diabetes is often the case of diabetic foot ulcers even amputation. The first step is prevention in saving the diabetic foot is by foot care. In addition, there should be early screening for diabetic foot to detect the risk of diabetic foot. This study aims to determine the relationship of foot care with the risk of diabetic foot in patients with type 2 diabetes in Haji Adam Malik Hospital in Medan. The study design used is the correlation with cross sectional analytic approach. There are a total of thirty patients with type 2 diabetes in the endocrine polyclinic outpatient unit at Haji Adam Malik Hospital which is taken through consecutive sampling techniques. The analysis used for this study was chi-square to determine the relationship of foot care with the risk of diabetic foot. The results showed that there were $83.3 \%$ of patients with good foot care; however, the remaining $30 \%$ of pasients have high risk of diabetic foot. Foot care and the risk of diabetic foot has a significant relationship with $\rho$ value $0,001(\alpha<0.05)$. Patients with good foot care have a chance of preventing the risk of diabetic foot ulcers at 6.25 times compared to those with less good foot care $(95 \%$ CI OR: 2,546 ; 15 344). This shows that good foot care can reduce the risk of diabetic foot. Therefore, nurses are expected to be able to routinely educate patients about foot care, the treatments of type two diabetes, diabetic foot risk assessment and also to provide support so that patients can control their blood glucose so it stays in the normal range.
\end{abstract}

Keywords - foot care, risk of diabetic foot ulcers, type 2 diabetes

\section{INTRODUCTION}

Diabetes mellitus (DM) is a metabolic disease that is marked by high levels of blood glucose resulting from defects in insulin secretion, impaired insulin activity or both which can cause serious problems and its frequency are increasing rapidly [1].

Data from the International Diabetes Federation (2013) states that the number of diabetic patients in the world until the year 2013 reached 382 million people and is predicted to continue to increase by $55 \%$ until the year 2035 with an estimation of 592 million people. Through epidemiologically, type 2 diabetes it is often undetectable and the start of diabetes is seven years before the diagnosis. Indonesia is a country that ranks seven of the ten countries with the highest number of cases of diabetes at the age of 20-79 years and the number of patients reached is 8.5 million people [2]

Based on the data from the National Diabetes Fact Sheet (2011), about $60-70 \%$ of people with diabetes experience complications such as neuropathy, mild to severe complications which would result in a loss of sensory and lower extremity damage [3]. Reference [4] found that $15 \%$ of people with diabetes will experience diabetic foot ulcers and up to $70 \%$ will experience amputation. Mortality and amputation of diabetic foot ulcers is still high at $16 \%$ for mortality and $25 \%$ for the amputation [5]. DM is estimated to be the main factor in $45 \%$ of all lower extremity amputations with $60 \%$ of non-traumatic amputations [6], [3]. Meanwhile, in 2014 at the Adam Malik Hospital, DM was included in one of the ten largest disease diagnosis at the inpatient and outpatient care unit and is the first case of most DM complications [7].

Given the number of people with diabetes which continues to increase and the cost of treatment of diabetic patients which were mainly due to the complications, the best decision is to take precautions. The success of preventive measures against complications is the patient's compliance in 
taking care of themselves or organizing themselves to control blood glucose levels to prevent injuries, as well as foot care which has been suggested by health personnel. Although the specific causes and pathogenesis of any complications are still observed, the condition of hyperglycemia appears to play a role in the disorder neuropathy and microvascular complications [8]. Efforts to prevent other complications are doing initial assessments to determine the risk of diabetic foot.

Starting from the assessment of diabetic foot and then classifying the risk of diabetic foot ulcers, then following up a plan is a nurse's obligation in providing nursing care in patients with DM. Education in diabetic patients and families is also a nurse's role in preventing the occurrence of diabetic foot ulcers. Appropriate education on foot care and early treatment is expected to prevent foot infections and ulcers to decrease risk of amputation [9].

From preliminary studies it is known that diabetic patients treated in Haji Adam Malik Hospital are DM patients with microvascular complications, macrovascular and neuropathic complications especially those with diabetic foot ulcers. At the wards, it is yet not available to do screening to format diabetic foot, resulting in nurses to not examine the risk of diabetic foot and diabetic foot ulcers. From this background, researchers are interested in studying the relationship of foot care with the risk of diabetic foot ulcers in Haji Adam Malik Hospital in Medan.

\section{METHOD}

The design of this research is the correlation with cross sectional analytic approaches that aims to determine the relationship of foot care with the risk of diabetic foot ulcers at the Adam Malik Hospital which samples at most 30 people with type 2 diabetes patients in the outpatient clinic of the endocrine department of Haji Adam Malik; this was taken through consecutive sampling techniques. The research sample criteria were patients with type 2 diabetes aged over 18 years whom did not have diabetic foot ulcers, they were able to treat themselves independently and were willing to engage in research.

The collecting data used instruments that involved literature in the form of a foot care questionnaire and risk assessment of diabetic foot ulcers. All respondents were assisted in filling the questionnaire with personal care and then continued with the examination of the patient's legs. Once data is collected, data processing and analysis is carried out. Analysis of the data includes univariate analysis to describe the characteristics of the respondent, foot care data and the risk of diabetic foot ulcers and bivariate analysis using chi-square to determine the relationship of foot care with the risk of diabetic foot.

\section{RESULT}

TABLE I

. DISTRIBUTIONS OF DEMOGRAPHY DATA PATIENT WITH TYPE 2 DIABETES IN H. ADAM MALIK HOSPITAL $(n=30)$

\begin{tabular}{|l|c|c|}
\hline Respondent characteristics & Frecuency & $\begin{array}{c}\text { Persentage } \\
(\%)\end{array}$ \\
\hline Age & 2 & \\
30-40 years & 9 & 6,6 \\
41-50 years & 14 & 30 \\
51-60 years & 5 & 46,7 \\
> 61 years & & 16,7 \\
\hline Sex & 17 & 56,7 \\
Women & 13 & 43,3 \\
Men & 2 & \\
\hline Education & 5 & 6,6 \\
SD & 18 & 16,7 \\
SMP & 5 & 60 \\
SMA & 3 & 16,7 \\
Post Graduate & 10 & 10 \\
\hline Occupation & 3 & 33,3 \\
Pension & 9 & 10 \\
PNS & 5 & 30 \\
Private employees & & 16,7 \\
Enterpreneur & 9 & 30 \\
Unoccupation & 15 & 50 \\
\hline Duration of Type 2 Diabetes & 6 & 20 \\
1-5years & & \\
6-10 years & & \\
>10 years & & \\
\hline
\end{tabular}

From Table 1 it is known that most respondents aged 51-60 years (46.7\%), over half of women $(56.7 \%)$, with the majority of high school education $(60 \%)$, employment of civil servants $(33.3 \%)$ and 
the majority suffering from diabetes for 6-10 years $(50 \%)$.

TABLE II

THE FREQUENCY DISTRIBUTION OF FOOT CARE AND RISK OF DIABETIC FOOT IN PATIENTS WITH TYPE II DIABETES IN H. ADAM MALIK HOSPITAL $(\mathrm{N}=30)$

\begin{tabular}{|l|l|c|c|}
\hline \multirow{2}{*}{ Variable } & \multirow{2}{*}{ Category } & \multicolumn{2}{|c|}{ Amount } \\
\cline { 3 - 4 } & & frequency & $\%$ \\
\hline Foot Care & Good & 25 & 83,3 \\
\hline & Not Good & 5 & 16,7 \\
\hline Risk of diabetic foot & Low & 21 & 70 \\
\hline & High & 9 & 30 \\
\hline
\end{tabular}

From Table 2 it is known that the majority of respondents do foot care as well $(83.3 \%)$, but as much as $30 \%$ of respondents have a high risk of foot ulcers.

TABLE III

RELATIONSHIP OF FOOT CARE WITH RISK OF DIABETIC FOOT IN PATIENT WITH TYPE 2 DIABETES IN H. ADAM MALIK HOSPITAL $(n=30)$

\begin{tabular}{|c|c|c|c|c|}
\hline \multirow[t]{3}{*}{ Variable } & \multicolumn{2}{|c|}{ Risk of foot ulcer } & \multirow{3}{*}{$\begin{array}{c}\text { OR }(95 \% \\
\text { CI })\end{array}$} & \multirow{3}{*}{$\begin{array}{c}\rho \\
\text { value }\end{array}$} \\
\hline & high & low & & \\
\hline & $f(\%)$ & $\mathrm{f}(\%)$ & & \\
\hline $\begin{array}{l}\text { Foot care } \\
\text { Not Good }\end{array}$ & $5(100)$ & $0(0)$ & 1 & \\
\hline Good & $4(16)$ & $21(84)$ & $\begin{array}{c}6.25 \\
(2.546- \\
15.344)\end{array}$ & 0.001 \\
\hline
\end{tabular}

Based on the analysis of foot care relationship with the risk of diabetic foot ulcers, it is shown that in Table 3 there are as many as 21 patients (84\%) that take good care of their foot which indicates the low risk of diabetic foot ulcers. Statistical analysis showed that there is a relationship between foot care with the risk of diabetic foot ulcers ( $p$ value 0.001, $\alpha:$ 0.05). Based on the OR, it can be concluded that patients who do good foot care can prevent the risk of diabetic foot ulcers at 6.25 times compared with patients who lacks treatment care (95\% CI OR: 2,546; 15 344).

\section{IV.DISCUSSION}

The results showed that most patients with type 2 diabetes take great care of their foot $(83.3 \%)$. From the bivariate analysis it was also known that good foot care leads to low risk in experiencing diabetic foot ulcers. This reinforces the statement that foot care in patients with type 2 diabetes is important to prevent the occurrence of diabetic foot ulcers. American Diabetes Association (2013) explains that foot care is very important for the patient to prevent diabetic ulcers and patients are encouraged to conduct inspections or foot care every day. Foot examination done every day will help reduce complications such as foot ulcers in diabetes [10]. This is related to the ease of implementation because it is independent and does not require special equipment [11].

From this research it was found out that the majority of respondents were aged over 51 years old (63.4\%), high school educated (60\%) and suffered diabetes for over 5 years $(70 \%)$. Reference [12] research states that there is no relationship between age, education, and long-suffering of diabetes on patients' ability to perform self-care DM. Reference [13] showed that low education and experience with diabetes for less than 5 years was associated with foot care knowledge and low foot treatment. Education generally will affect the person's ability to understand the information. Results showed that $30 \%$ of type 2 diabetic patients in endocrine polyclinic of Haji Adam Malik Hospital have a high risk for diabetic foot ulcers. In addition there are four people who take care of their foot well, but have a high risk of experiencing diabetic foot ulcers. This can happen due to many factors that influence the risk of diabetic foot ulcers, such as poor blood sugar control, diet is not appropriate, previous ulcer history, less activity and duration of diabetes type 2. A person suffering from diabetes mellitus at a long period of time and does not get special attention are more at risk of ulceration. Suffering from diabetes for a long period of time affects the incidence of complications of diabetes mellitus type II. This is consistent with [14] explanation which explains that suffering from diabetes mellitus for more than 5 years will lead to a variety of chronic complications such as neuropathy and angiopathy caused by blood glucose levels which are not controlled.

The risk factor for the occurrence of diabetic foot ulcers include peripheral neuropathy, foot deformities, peripheral vascular disease, trauma, and a history of foot ulcers or previous amputation [15]. Therefore, it is important for patients to know 
these risk factors in order to make the prevention of diabetic ulcer risk early on. Reference [15] explains that the necessary steps of foot care for patients at risk of diabetic foot ulcers is to do feet inspections daily, first aid to trauma, foot care, nail and skin of the foot, reducing the risk of trauma and infection as well as use appropriate footwear.

Based on the results of the bivariate analysis in this study, it has been shown that there was significant relationship between foot care with the risk of diabetic foot ulcers. Patients who do good foot care have a chance of preventing the risk of diabetic foot ulcers at 6.25 times compared to those with less good foot care (95\% CI OR: 2,546; 15 344).

One of the necessary precautions to reduce the risk factors is by performing checkups and foot care. The appropriate education on foot care and early treatment is expected to prevent foot infections [9]. Hence, the nurse is responsible for the management of diabetic patients, including assessment, education and direct care. Educate patients about proper foot care and regular foot examination is very effective in preventing ulcers and ulcer risk becoming amputated [16]. Therefore, to prevent the occurrence of ulcers diabetic patients need to take care of their feet at a preventive nature, blood glucose control through the adjustment of diet, exercise and therapy.

\section{V.CONCLUSIONS}

The study concluded that most patients do well at foot care and with only a small proportion that is at risk of diabetic foot ulcers. There is a significant correlation between the treatments of diabetic foot with the risk of diabetic foot ulcers in patients with type 2 diabetes in the endocrine polyclinic at Haji Adam Malik Hospital Medan. Health workers at Haji Adam Malik Hospital especially the nurses should provide a structured education about the importance of foot care to prevent the risk of diabetic foot ulcers and amputations. Also, nurses need to do screenings for diabetic foot, diabetic foot ulcer risk classifications and a follow-up treatment plan of diabetic foot. Furthering, the study examines other factors that influence the occurrence of diabetic foot ulcers, appropriate interventions for preventing diabetic foot ulcers, the ability of nurses to do screenings for diabetic foot and examine the qualitative experience of patients in the control of blood sugar and to prevent diabetic foot ulcers.

\section{ACKNOWLEDGMENT}

Thank you profusely to SIMLITABMAS DIKTI, University of Sumatera Utara and H. Adam Malik Medan Hospital who have supported this research to complete. Hopefully all the help, guidance and input from the author received reciprocated profusely from God Almighty.

\section{REFERENCES}

[1] LeMone, P, and Burke, Medical Surgical Nursing : Critical Thinking in Client Care,4th ed., New Jersey: Pearson Prentice Hall, 2008

[2] International DM Federation, IDF DM Atlas, 6th ed., The International DM Federation, 2013.

[3] National DM Fact Sheet.(2011). Fast Fact on DM. [Online]. Available: https://www.cdc.gov/diabetes/pubs/pdf/ndfs_2011.pdf

[4] Forlee, M, "What is the diabetik foot?," $C M E$, vol.28 No.4, pp.152156, April. 2010

[5] Sudoyo, A, W., Setiyohadi, B., Alwi, I., Simadibrata, M \& Setiati, S., Buku Ajar Ilmu Penyakit Dalam. $5^{\text {th }}$ ed., Jakarta: Interna Publishing, 2009

[6] Heitzman, J, "Foot care for patients with DM,". Topics In Geriatric Rehabilitation, vol. 26 (3), pp. 188-191, March. 2010.

[7] Tahun 2014 RS Adam Malik Medan Tangani 181.329 Pasien, Daily Sinar Indonesia Baru. Jan 7, 2015 [Online]. Available: http://hariansib.co/view/Medan-Kita/42123/-Tahun-2014-RS-AdamMalik-Medan-Tangani-181-329-Pasien.html

[8] Smeltzer, S, \& Bare, Brunner \& Suddarth's Textbook Of Medical Surgical Nursing. Philadelpia : Lippincott, 2008.

[9] Black, J.M and Hawk, J.H, Medical Surgical Nursing Clinical Management for Positive Outcome, $8^{\text {th }}$ ed., Singapore: Elsevier Pte Ltd, 2009.

[10] American Diabetes Association. "Diagnosis and classification of diabetes mellitus". Diabetes Care Journal Vol. 36. Suplemen 1, pp.S67-S74, Jan. 2013. [Online]. Available: http://care.diabetesjournals.org/content/diacare/36/Supplement_1/S67.f ull.pdf

[11] Wright, K., and Ojo, O. "Foot care for residents with type 2 DM". Nursing and Residential Care, vol.12 (12), pp.585-589. Des. 2010.

[12] Ariani, Y., Sitorus, R., and Gayatri, D., "Hubungan antara motivasi dengan efikasi diri pasien dm tipe 2 dalam konteks asuhan keperawatan di RSUP H. Adam Malik Medan".thesis. University of Indonesia, Depok, Indonesia, Jan. 2011.

[13] George, H., Rakesh PS, Krishna, M., Alex, R., Abraham, J.V. George,K., and Prasad, J. H., "Foot care knowledge and practice and prevalence of Peripheral neuropathy among people with diabetes attending a secondarycare rural hospital in Southern India”. J Family Med Prim Care. Vol. 2(1), pp. 27-32, Jan. 2013

[14] Boulton, A.J.M., Amstrong, D.G., Albert, S.F., Fryberg, R.G., Hellman, R., Kirkman, M.S., "Comprehensive foot examination and risk assessmen”. DM Care Journal. vol. 31(8). Pp. 1679-1685, August. 2008.

[15] May, K, "Preventing foot Ulcers", Aust Prescr, vol 31:94-6. Aug.2008.

[16] Singh, N., Amstrong, D.G., dan Lipsky, B.A. (2005). Preventing foot ulcers in patients with DM. JAMA. 12:293(2): 217-28. Jan. 2005. 